\title{
„FOLYÉKONY ÖRÖKSÉC” A MARRÁKESI VI. MOHAMED VÍZ MÚZEUMBAN
}

FÜLÖP ZOLTÁN OTTÓ

Az anyagi kultúra megőrzésével, konzerválásával és közvetítésével kapcsolatban a kulturális reprezentáció kérdésköre az 1980-as évektől válik a történet- és társadalomtudományok egyik kulcsfogalmává a diszciplínában végbemenő kulturális fordulatoknak ${ }^{1}$ köszönhetően. A tudományos megfigyelés a múzeumi közegre, mint a társadalom nyilvános terére összpontosul. A diskurzusban a fö irányokat a történeti múlthoz füződő viszony új alapokra helyezése jelenti. A szövegként felfogott kultúrából [writing culture] (Clifford - Marcus, 1986.) a kiállított kultúra felé [exhibiting culture] (Karp - Lavine, 1991.) történő hangsúlyeltolódás maga után vonja a gyüjtemények, az általuk elmondott narratívák, a reflexív nézőpont előtérbe kerülését, ami a kurátori praxist is formálja. A múzeum mint egyfajta médium ${ }^{2}$ nem pusztán gyüjt, megóv, ismereteket közvetít, hanem folytonos reinterpretációra ad lehetőséget, többek között olyan kérdéseket állítva az előtérbe, mint a polivokalitás és az intézményi kommunikáció. (Wilhelm, 2013: 9-14.) A kulturális reprezentációt sajátos értelemadási eljárásként felfogva (Korff - Roth, 1990.; Lidchi, 1997.; Clifford, 1999.) felértékelődik azon kiállítási stratégiák alkalmazása, amelyek meghaladják a tárgyak, képek, dokumentumok bemutatását és a hangsúlyt a gyüjteményezési szempontok, a jelentésösszefüggések újrafogalmazására, az alternatív térhasználatra, a performativitásra helyezik. E módszertani és tematikus változások együtt járnak a bemutatóterek újragondolásával és a disszemináció előtérbe helyezésével. A posztkoloniális fordulatot ${ }^{3}$ követően a figyelem az Európán kívüli világokra irányul és az 'alteritás', a 'hatalom', a 'transznacionális' fogalmak a vizsgálatok homlokterébe kerülnek. A globális téri átrendeződésre reflektálva a re-mapping jegyében kerül sor a világ újrafelfedezésére, így a korábban perifériára szorult földrajzi, politikai térségekhez az eddigiektől eltérő kulturális jelentéseket társítanak. (Bachmann-Medick, 2007.) Az alábbi marrákesi esettanulmány példaként szolgál a múzeumi boom következtében végbement irányváltásra, egyúttal a hagyományos muzeológiai paradigmáktól való elmozdulásra, emellett ráirányíthatja a figyelmet az örökségkezelés sokoldalú, kontextusfüggő, kulturális megértésen alapuló vonatkozásaira.

A kulturális örökség megörzésében világszerte kiemelt helyet foglalnak el a memóriaintézmények, ez alól az északnyugat-afrikai térség sem kivétel. Marokkóban az ezredfordulót követően egyes létesítmények a vizuális beszédmódok, a 
tárlatrendezés és az építészeti megoldások új lehetőségei felé nyitva igyekeznek a nemzetközi múzeumi vérkeringésbe bekapcsolódni. A kultúrára társadalomszervező tényezőként tekintve keresnek választ a posztkoloniális lét kihívásaira lokális, nemzeti és globális szinten. Központi küldetésüknek tekintik megörizni a múlt emlékeit és azok újraértelmezése révén kiállítási tevékenységükkel reflektálni az örökségre. A vízkincs mint természeti erőforrás anyagi kultúrán nyugvó megóvásában és reprezentálásában jelentős szerep jut az afrikai kontinensen a márrakesi tematikus múzeumnak. Az itt létrehozott tárlat a kontextusváltásból adódó tárgy- és időkezelés többrétegúségét példázza, egyúttal visszatükrözi a recens, plauzibilis muzeológiai tendenciákat. A nem-szokványos épület, a rendhagyó kiállítási környezet és a gyüjtemény közötti kapcsolat értelmezése, a jelentéstartalmak és a reprezentációs technikák közötti összefüggések felfejtése, valamint a rendezési elvek mögött meghúzódó kurátori és intézményi szándék feltárása hozzájárul a múzeum új szerepkörének megvilágításához.

A Musée Mohammed VI. pour la civilisation de l'Eau au Maroc (a továbbiakban: VI. Mohamed Víz Múzeum) Marrákesben az 1985-ben az UNESCO által világörökségi helyszínné nyilvánított medinától távol, a Tensift folyón átívelő híd és a La Palmeraie közelében található. A Casablanca felé vezető úton haladva már távolról szembeötlik az erős vizuális hatású szimbolikus épület, amelyben a kortárs mediterrán és afrikai múzeumi diskurzust erősen befolyásoló vízkincs gyüjteményi tematizálása valósul meg.

Az intézmény azzal a céllal jött létre, hogy bemutassa a marokkói vízgazdálkodáshoz kapcsolódó évezredek alatt felhalmozott tudásanyagot és azt az ország komplex örökségkezelési stratégiájába integrálja. A létesítmény mottója a Koránból vett idézet - „... Megtettünk a vizből minden dolgot élővé...”4 - arra utal, hogy az

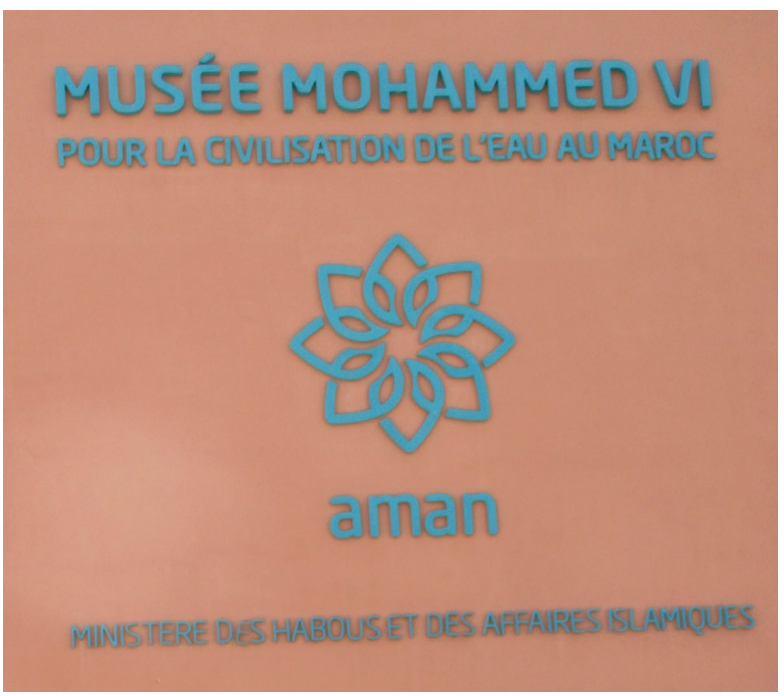

1. kép A VI. Mohamed Viz Múzeum bejárati felirata. Forrás: Saját felvétel. 


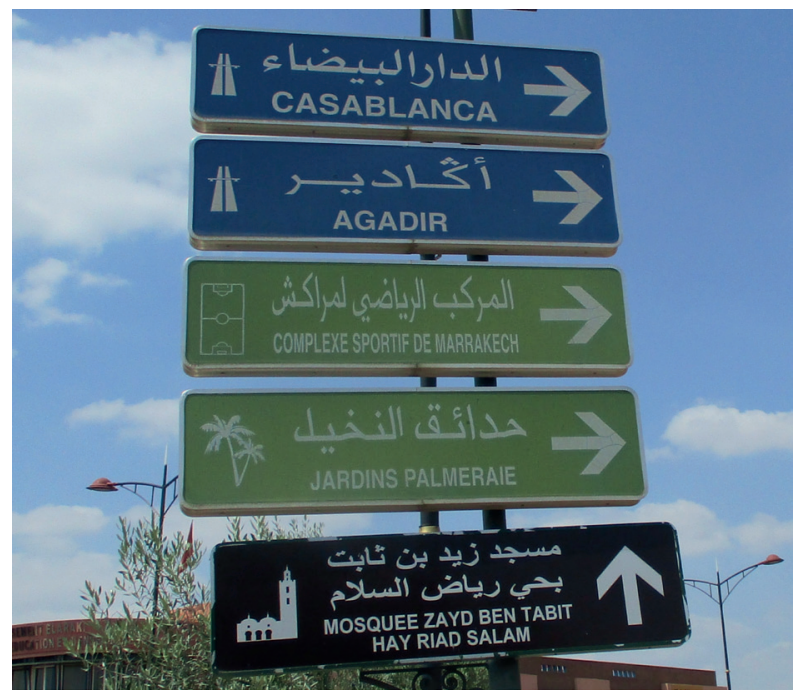

\2. kép Úton a VI. Mohamed Viz Múzeum felé. Forrás: Saját felvétel.

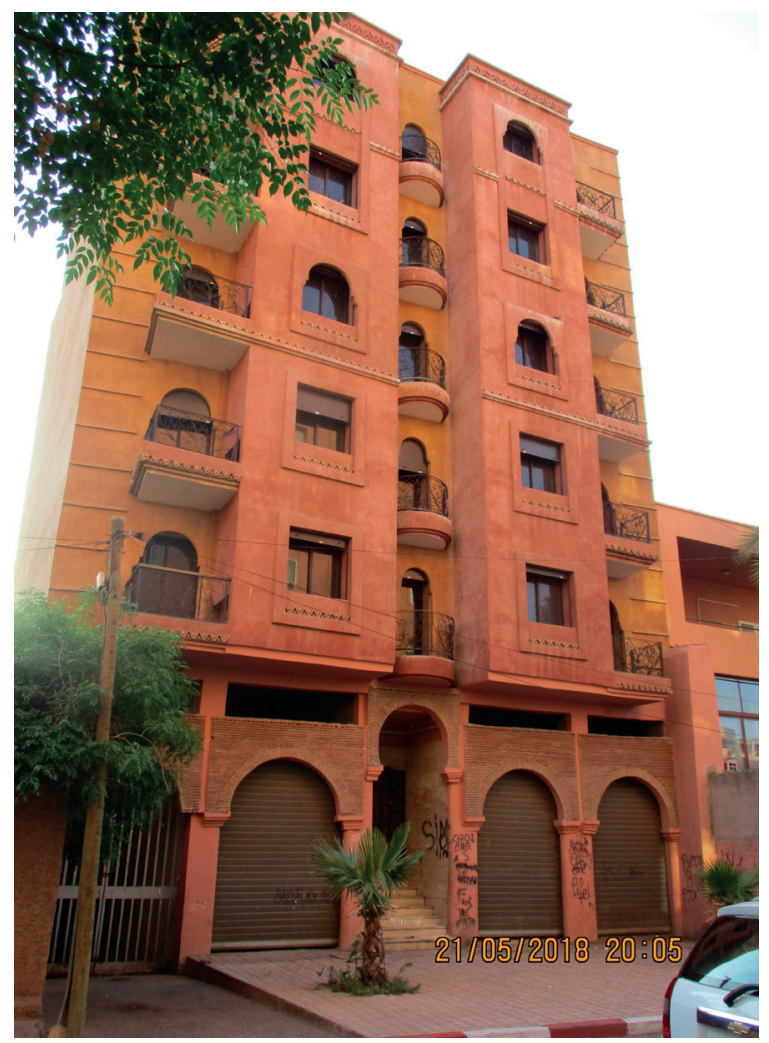

\3. kép Az Al Hamra egyik jellegzetes vörös homokkö épülete. Forrás: Saját felvétel.

Fülöp Zoltán Ottó: „Folyékony örökség” 
arab kultúrában kiemelt helyet tölt be a víz, amelyre a termékenység és a megtisztulás jelképeként, mintegy égi ajándékként tekintenek. Erről tanúskodnak többek között a hammamok, valamint a mecsetek szökökútjai is, amelyek a település tervszerü vízgazdálkodásának kiépítését megelözően évszázadokon át szolgáltatták a vizet a lakosság számára. Történeti távlatban a múzeum elött müködő szökőkutak a fallal körülvett, labirintusszerủ óvároson kívüli fő ivóvízellátási pontoknak számítottak.

A múzeum Marrákesbe helyezése önmagában is újszerü szemléletet tükröz, hiszen a város távol az Atlanti-óceántól, a Magas-Atlasz lábánál fekszik. A település északi bejáratánál, az oázis szélén elterülő ikonikusnak, nemzetközi színtéren is ízlésformálónak tekinthető épület a kontinens egyik leglátványosabb, legmodernebb kulturális helyszíne. Építészeti nyelve igazodik a múzeumépítések 21. századi globális tendenciáihoz, formabontó architektúrája a „primadonnaépitészetnek” (Beier-de Haan, 2005: 22.) nevezett irányzat egyik példája. A rendhagyó kivitelezés kedvezően hat a tekintetben is, hogy az intézményre széleskörü médiafigyelem ${ }^{5}$ irányuljon. Az épület vezetőtervezője Rachid Skali Houssaini építészmérnök. A projekt kidolgozásában és megvalósításában számos tudományág képviselői működtek együtt: többek között történészek, mérnökök, örökségszakértők, természettudósok, vízügyi szakemberek részben a neves helyi egyetemről, az Université Cadi Ayyad-ról. Az átfogó tervek kivitelezését irányító londoni székhelyü Museums and Expos International Limited (MUSE) építészei gazdag referenciákkal rendelkeztek, hiszen nevükhöz füződik többek között a 2008. évi Zaragozában megrendezett „Viz az életért” (Water for Life) mottójú szakexpón a Víztorony pavilon (Water Tower Pavilion) és a kuvaiti pavilon megalkotása, ez utóbbi belső térkialakítása rokonságot mutat a VI. Mohamed Viz Múzeum installációs megoldásaival.

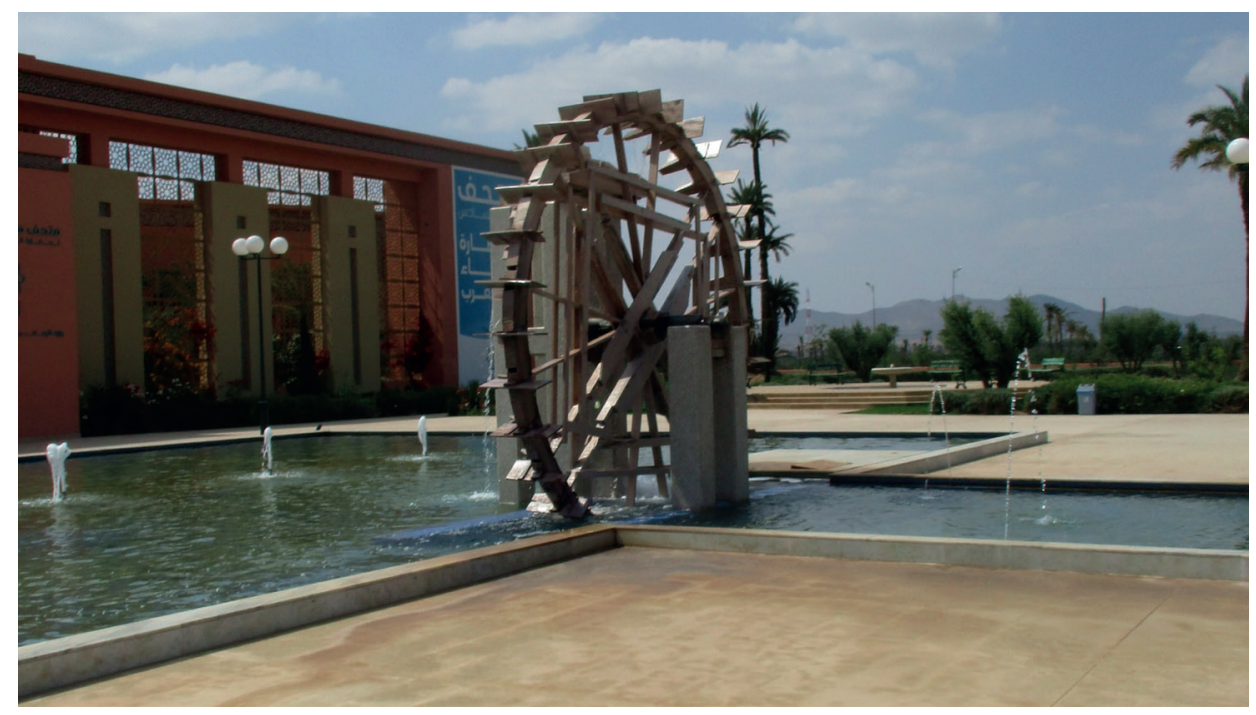

4. kép Vizemelö kerék a VI. Mohamed Viz Múzeum elött. Forrás: Saját felvétel. 


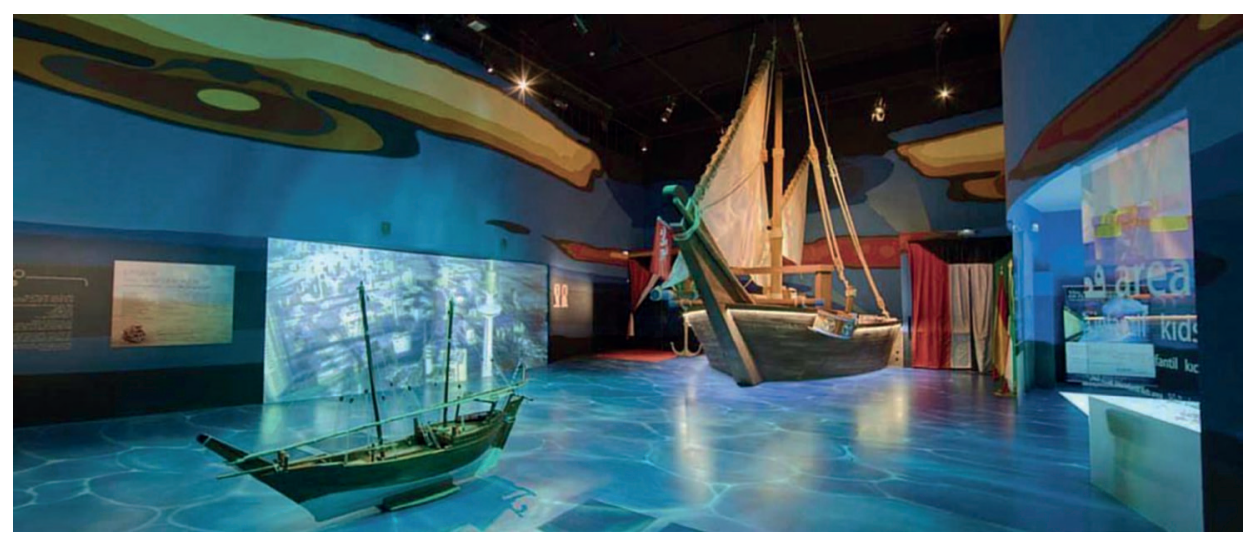

\5. kép A kuvaiti pavilon egyik emblematikus része a zaragózai vízexpón.

Forrás: http://www.museintl.co.uk/portfolio-item/kuwait-pavilion/

A memóriaintézmény tagja az UNESCO által a kormányközi hidrológiai program (Intergovernmental Hydrological Programme) keretében létrehozott víz-múzeumok globális hálózatának (Water Museums Global Network). ${ }^{6}$ Stratégiai partnerséget alakított ki a GIZ-zel (Deutsche Gesellschaft für Internationale Zusammenarbeit $G m b H$, Német Nemzetközi Együttmüködési Társaság Kft.), valamint a rabati egyetemen müködő CNRST-vel (Centre National pour la Recherche Scientifique et Technique, Nemzeti Tudományos és Müszaki Kutatóközpont). J Jelentőségét aláhúzza, hogy a létesítményt 2017 januárjában az Alavita-házi Moulay El Hassan (2003-) koronaherceg avatta fel az uralkodói család több tagjának jelenlétében, majd mintegy öt hónap múlva a múzeumi komplexum megnyitotta kapuit a közönség elött. Az épületegyüttest négy fő egység alkotja: a tárlatoknak helyet adó föépület, az oktatási pavilon, az informatikai terem, valamint a zöldövezetként szolgáló pálmaliget, amelynek revitalizációjával a múzeum a falakon túlmutató (musée au-delá des $m u r s)^{8}$ kulturális térré bővült. A tájrendezésbe integrált építmény egyúttal a jó ökológiai gyakorlatok demonstrációs helyszínévé is vált. A parkban tett kellemes séta során a látogatók megismerhetik a Marokkói Királyság kertépítészeti tradícióit, öntözéstechnikáit.

A Ministérie des Habous et des Affaires Islamique, vagyis az iszlámügyi minisztérium fenntartásában lévő intézmény állandó és időszaki kiállításoknak, valamint efemer eseményeknek egyaránt otthont ad. Az egyszerre mintegy háromszázötven fö befogadására alkalmas kulturális központ egész évben rendszeresen fogad csoportokat elsődlegesen Marrákesböl, valamint Al Haouz tartományból. A háromszintes épületbe lépve az érdeklődőt egy hatalmas fogadócsarnok várja, ahonnan a látogató a kiállítóhelyiségekhez juthat el. Az útvonalat úgy alakították ki, hogy a magasságbeli adottságokat hasznosítva a belső köralakú központi részen összeérnek a különféle szcenírozási technikák mentén szervezett terek, ezáltal sajátos proxemika alakul ki. Az egyes gyüjteményi egységek között mozgólépcső könnyíti meg az átjárást. 

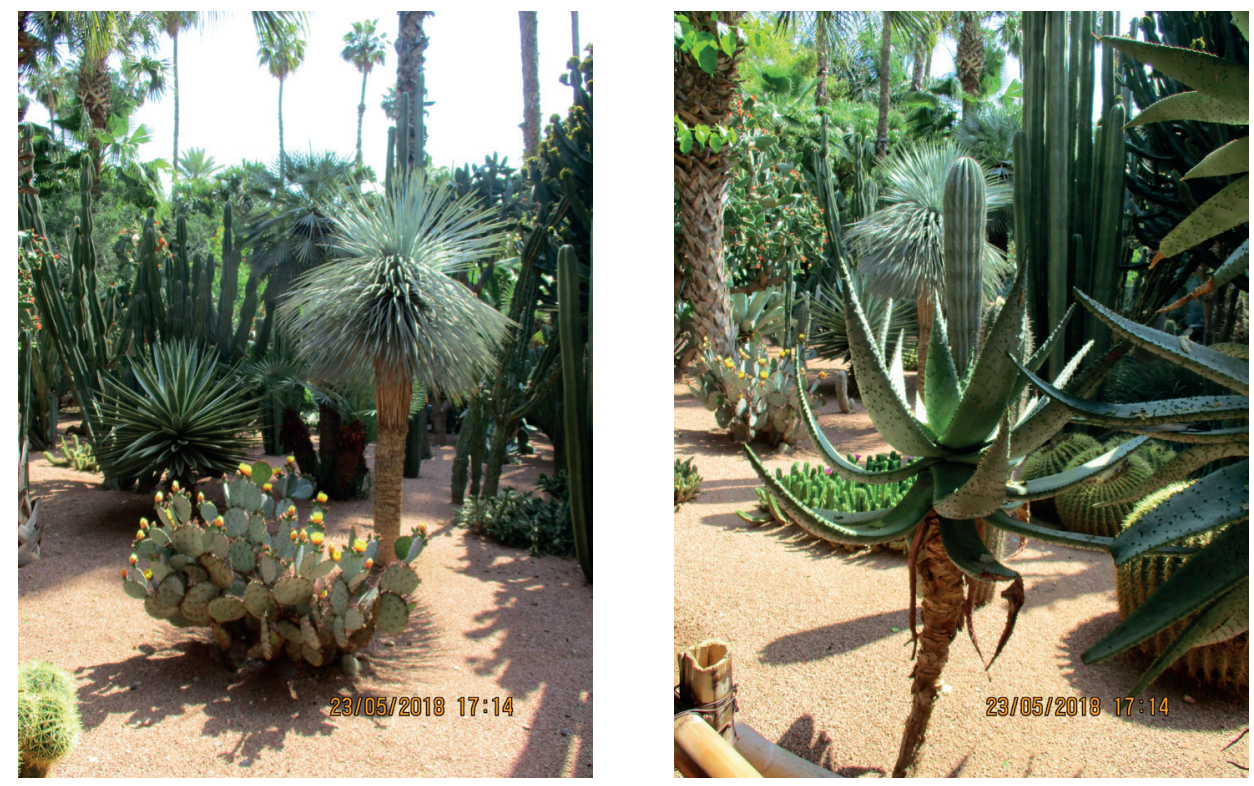

^ 6.-7. kép Felvételek a múzeumot övezö pálmaligetröl. Forrás: Saját felvétel.

Afrika egyik legnagyobb tematikus intézménye ${ }^{9}$ tárgykörök szerint mutatja be a víz történelmi és kulturális szerepét, a hozzá kötődő szellemi tartalmak sokszínűségét, tervszerü felhasználásának módjait. A vízgazdálkodás számos aspektusát érintő bemutatóterek visszatükrözik a marokkói örökségfelfogás lényegét, miszerint az örökség nem állandó, hanem élő és dinamikus, folytonosan alkalmazkodik az „itt és most" körülményeihez, a kulturális csere révén hagyományozódik és válik megismerhetővé. E látásmód nem a múlt javainak passzív átvételéből táplálkozik, hanem az aktuális jelenre vonatkoztatott, a megváltozott tudásra és tapasztalatra épített értelemadási eljárást jelent, amelyben a múlthoz való újfajta viszonyulás nyilvánul meg. E megközelítésben az egymást követő nemzedékek nemcsak átöröklik elődeiktől a már meglévő kulturális mintát, hanem azt szüntelenül újratermelik, időről időre új, kreatív válaszokat fogalmaznak meg, így kapcsolva össze az idősíkokat.

A múzeum az arab kultúra vízhez kötődő társadalmi gyakorlatait, szokásait jól megtervezett keretrendszerben innovatív módon teszi közzé. A kulturális örökség változásait folyamatszerủen modern technikai eszközökkel mediálja a széles közönség felé, amely a víz sokrétủ értékének tudatosítását és a hozzá társított ismeretek elmélyítését szolgálja. A tárlat többféleképpen láttatja a marokkói, tágabb spektrumban a muszlim hidraulikus örökséget. Az észak-nyugat afrikai vízgazdálkodás eltérő kontextusait a „folyékony örökség” szociális, kulturális, ipari, technológiai metszetü reprezentálásán keresztül közvetíti a látogatók felé. Az intézmény a víznek az ország történelmében és örökségalkotásában történő hangsúlyozásán túl arra törekszik, hogy egyfajta modern interaktív központként globális szintủvé szélesítse a vízkincs 
történeti értelmezését. Emellett felfedezhető egyfajta explicit politikai szándék is, mégpedig emléket állítani II. Hasszán ${ }^{10}$ király vízpolitikájának - különös tekintettel az 1983. évi nagy szárazság és az 1996. évi áradások idején tett erőfeszítéseire -, egyben megörökíteni fia, VI. Mohamed ${ }^{11}$ vízgazdálkodás területén elért gazdasági és technikai eredményeit. A létesítmény ezen túlmenően ismerteti a Marokkói Vízügyi Iskola (École Marocaine de l'Eau) oktatási hagyományait is. Ezáltal olyan múzeumi modell valósul meg, amelynek fö pillérei az örökség megörzése, egyfajta modern nemzetközi tudásközpont kialakítása, valamint „a falakon túlmutató múzeum” létrehozása.

Az intézményi szemléletnek megfelelően a víz az emberi civilizáció egyik alkotóelemeként jelenik meg. A kiállítás idővonala több ezer évet fog át, hiszen az ősi tudástól jut el a legmodernebb kortárs technológiáig, vagyis feldolgozva a múltat fordul a jövő kihívásai felé. A létesítmény a víz és az ember közötti kölcsönös és összetett viszonyt különféle nézőpontokból ábrázolja. A kurátori elgondolás felhívja a figyelmet a víz fenntartható használatra, az éghajlatváltozás élővilágra gyakorolt hatásaira, reflektál az egész világot egyre közvetlenebbül fenyegető ivóvízhiányra, valamint az óceánok vízgazdálkodásban betöltött szerepére. Emellett az ország vízkincsének teljességre törekvő feltérképezését is elvégzi, amelynek során a vízhez kapcsolódó rituális, spirituális tartalmakat, hiedelmeket is megismerteti. Az intézmény egyéb feladatokat is ellát. Az épületben helyi, országos és nemzetközi szemináriumokat tartanak, tematikus workshopokat szerveznek, ezen túlmenően konferencia- és számítógépterem, médiatár, levéltár, könyvtár, valamint kávézó és könyvesbolt müködik. Rendhagyó múzeumi térként imahelyiséget is berendeztek.

A gyüjtemény gazdag tárgyanyagot ölel fel. A tárlaton hangsúlyt kap az öntözőrendszerek, a vízgyüjtők, a nória ${ }^{12}$ müködésének, valamint az esővíz gyüjtésének és újrafelhasználásának színrevitele. Vízórák, vízvezetékek, hajók is az installáció szerves részei, ezen túlmenően csatornák makettjei, kutak, vizes blokkok is megjelennek a kiállításon. Láthatók itt még vízrajzi térképek, kéziratok, fényképek és egyéb dokumentumok, a nagy marokkói ökoszisztémák - az oázisok, a hegyek, a síkságok és a Szahara - kicsinyített mása, mindemellett valósághủ reprodukciók is helyet kapnak. A témától elválaszthatatlan vízimalmok története is feldolgozásra kerül, hiszen a Magas-Atlasz lábánál e hagyományos vízemelő szerkezeteknek hosszú időn át megkülönböztetett helye volt a gazdasági életben. A víz szerepének a bör-, a cukorgyártásban, illetve a sóüzemekben történő bemutatására szintén teret biztosítanak. Megismerhetők továbbá Fez, Marrákes, Teután vízgazdálkodási módszerei is. Tárlatlátogatás közben a háttérben autentikus afrikai zene szól.

A vízkincs problematikája által a közönség megszólítása többféle módon és eszközzel történik. A kísérőszövegek narratív formában arab, francia és angol nyelven mondják el a víz és a vízgazdálkodás történetét Marokkó jellegzetes földrajzi területeinek példáján. A tárlaton a mezőgazdasági termelékenység fokozását megcélzó oktatási segédanyagok, valamint eddig még nem publikált tudományos eredmények is helyet kapnak. A didaktikus jelleget felerősíti a látványos szcenírozás, valamint hang- és fénybemutató, ami a víz fizikai-kémiai tulajdonságait és természetes kör- 
forgását bemutató installáció során is kifejezésre jut. A vízmolekulák által inspirált látvány futurisztikus légkört kölcsönöz.

A tudásközvetítésben az érzékszerveknek fontos szerep jut. Az expresszív kiállítási élményt szolgálják a különböző audiovizuális eszközök, a feliratok, az animációk, a film-, a videó- és a $360^{\circ}$-os diavetítések, amelyek segítségével a látogatók betekintést nyerhetnek a víz történetébe. A formabontó terek, a multimediális eszközök egyidejü áradatában ugyanakkor a figyelem könnyen szétszóródhat, hiszen a betérőnek a színes falfelületek, fény- és hanghatások, kisfilmek és interaktív játékok sűrủ útvesztỏjében nincs módja és lehetősége valódi befogadóvá válnia. Aligha akad az ideérkezők között olyan, legyen az bármilyen céltudatos múzeumlátogató is, aki az egyébként strukturált kiállítási útvonalról le ne térne az érzékszervekre ható ingereket követve. Ez az intenzív belső térélmény a figyelem megosztódásához vezethet.

A látogatóközpontot sikerült becsatornázni a teljes oktatási-nevelési rendszerbe. Az óvodások és a kisiskolások számára múzeumpedagógiai foglalkozásokat biztosítanak, cserediákprogram keretében dél-európai - elsősorban spanyol, francia és olasz - hallgatókat fogadnak. Igény szerint tematikus sétákat tartanak a pálmaerdőben. A szervezett túrák alkalmával különböző demonstrációs és disszeminációs segédeszközöket használnak fel. Az ideérkezőt magával ragadhatja a rehabilitált múzeumi környezet, a rendhagyó kiállítótér és az invenciózus építészeti megoldás. A holisztikus szemlélet jegyében itt éppúgy elmélyíthetik ismereteiket azok, akik a

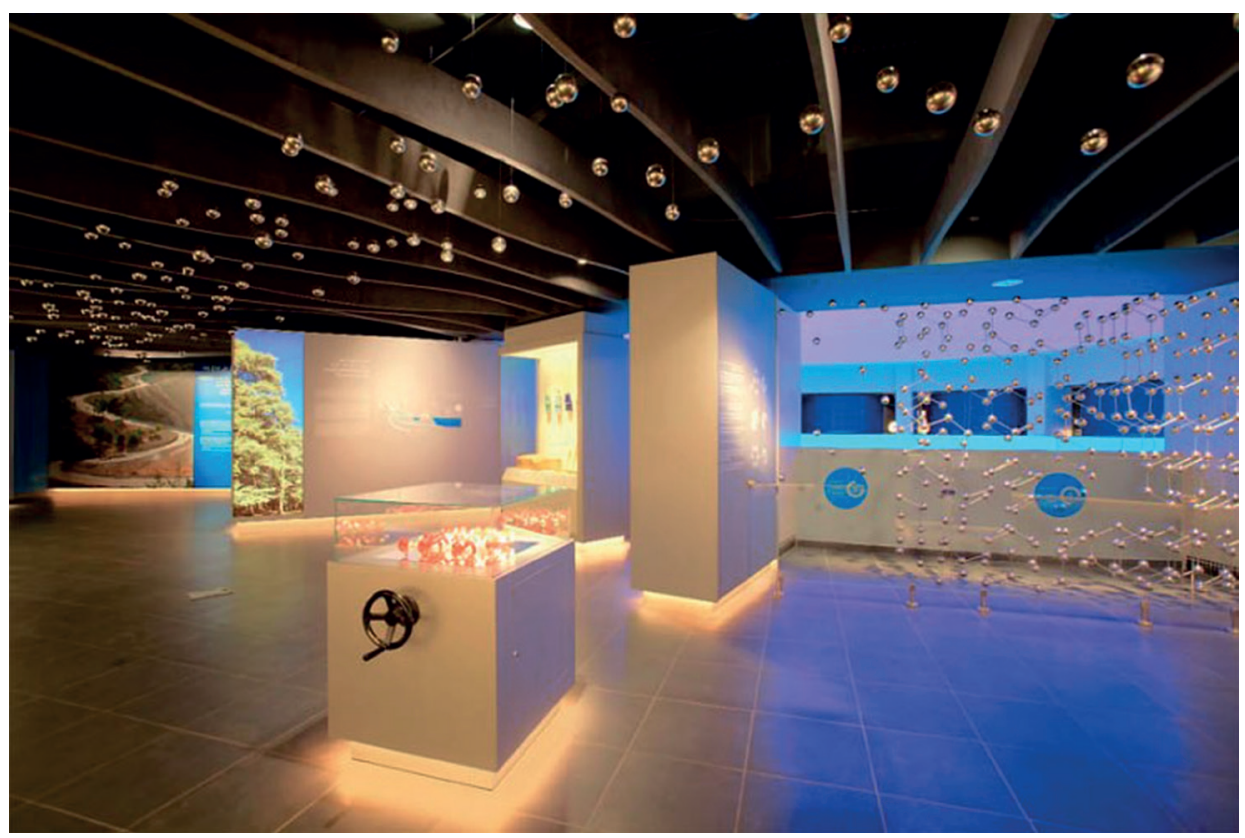

\8. kép A viz tulajdonságait szemléltető installáció a VI. Mohamed Viz Múzeumban.

Forrás: https://leseco.ma/maroc/marrakech-un-musee-dedie-a-l-eau-ouvrira-en-mai.html 
víz történelemformáló szerepe iránt érdeklődnek, mint akik a müszaki tudományok, a földrajz, a geopolitika, valamint az alkalmazott kémia kérdésfeltevéseire nyitottak. E tekintetben a múzeum olyan kulturális közegnek tekinthető, amely a szórakoztatva tanulás jegyében ismerteti meg a víz történetét, a különféle vízgazdálkodási projekteket, a hidraulikus berendezéseket és a természeti környezetet. Az intézmény így szervesen kiveszi a részét az Al Hamra idegenforgalmából és kulturális iparából csakúgy, mint ahogy a következő antropológiai múzeum is.

A Musée Tiskiwin (Tiskiwin Múzeum) a Mellah Kasbah zsidónegyedhez közel, a Palais de la Bahia (Bahia Palota) és Musée Dar Si Saïd (Dar Si Saïd Múzeum) között egy felújított, nagy alapterületü, 20. században épült riadban kapott helyet, abban a házban, ahol Bert Flint holland kulturális antropológus élt és dolgozott. A múzeum

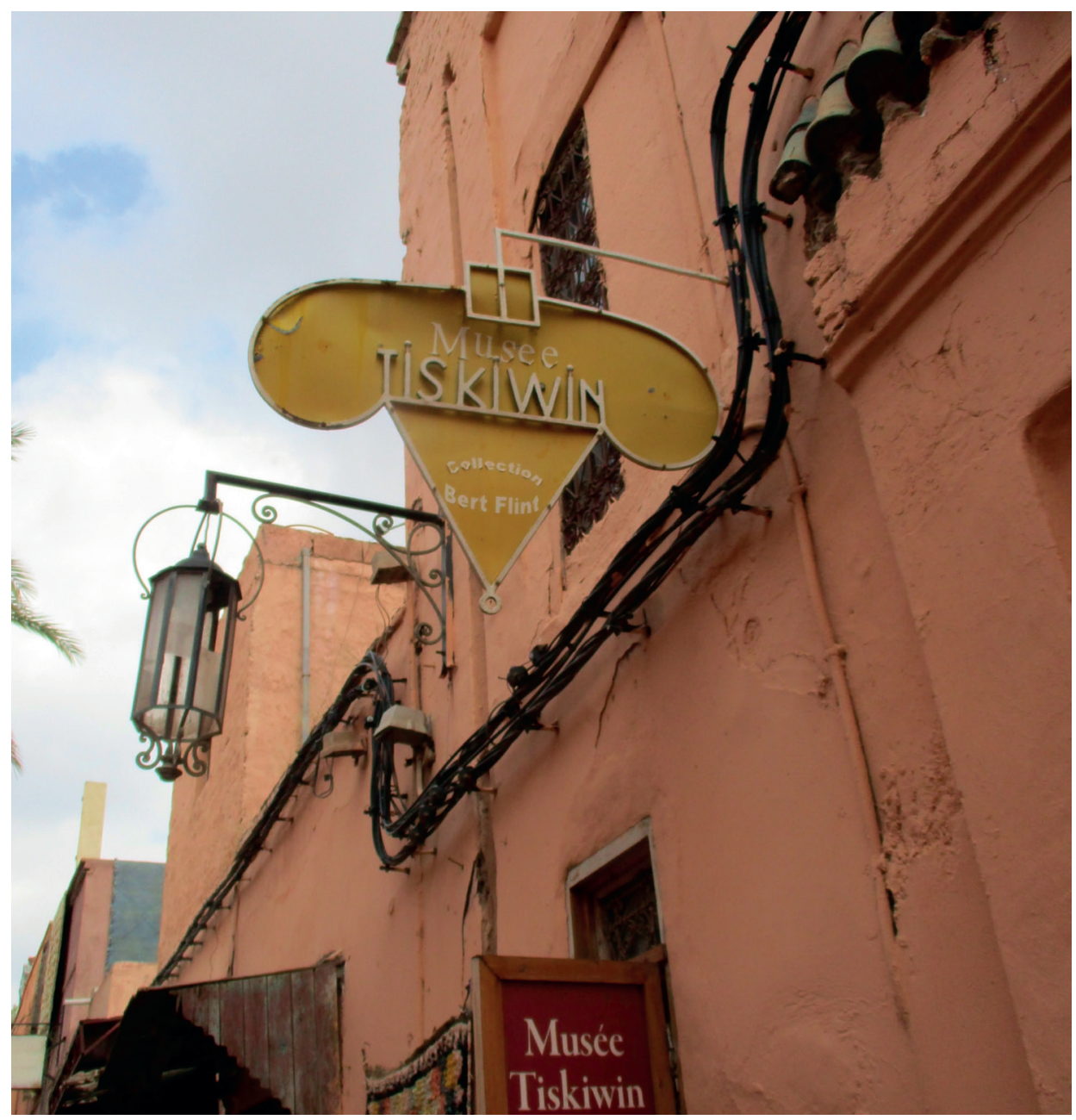

^9. kép A Musée Tiskiwin bejáratát jelzö tábla. Forrás: Saját felvétel. 


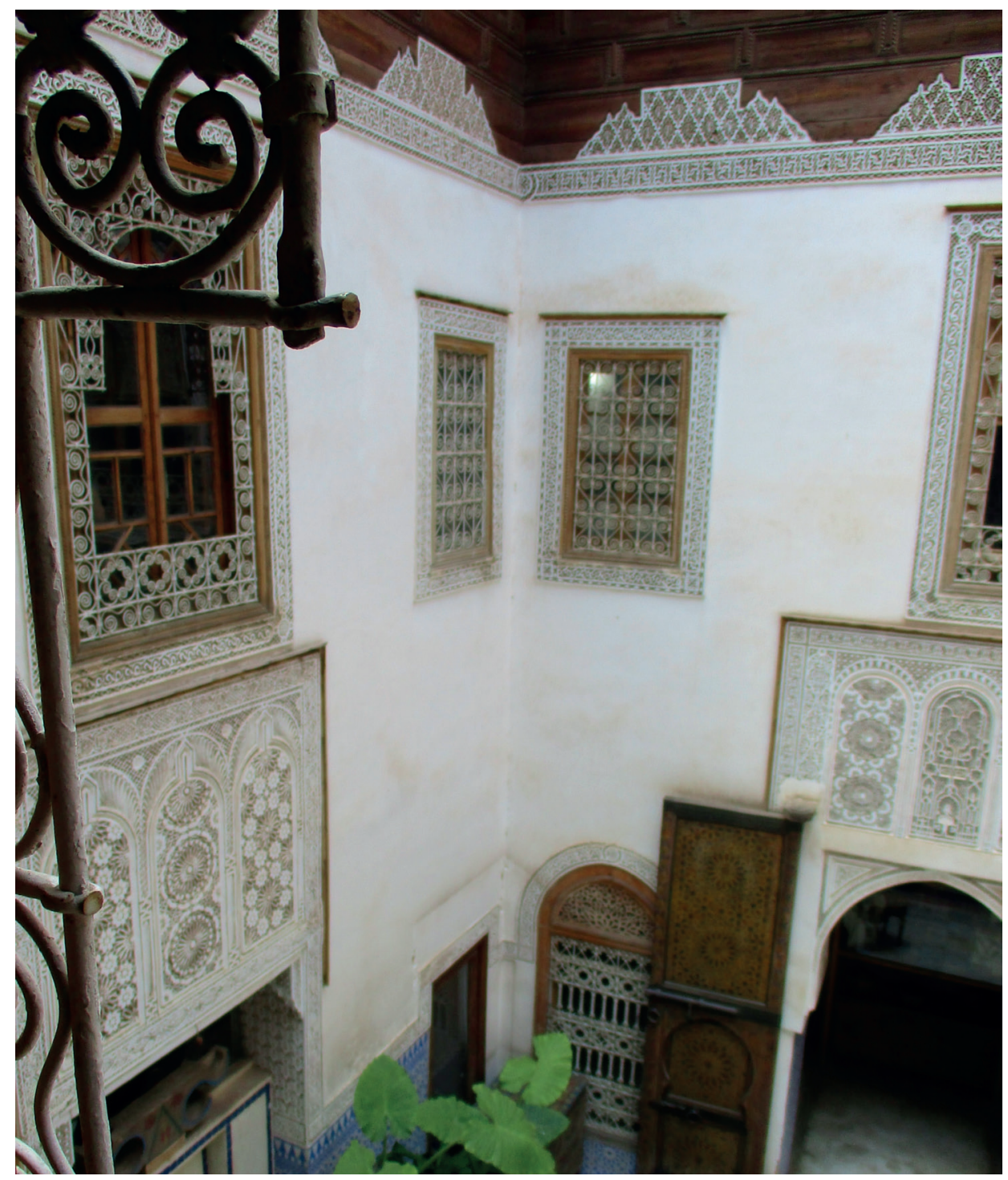

^10. kép A Musée Tiskiwin belsö udvara. Forrás: Saját felvétel.

anyaga - amelyet szintén az Université Cadi Ayyad szakemberei gondoznak - a németalföldi társadalomkutató által felhalmozott tárgyak gyüjteménye. A kiállítás címe Un voyage à travers le Sahara, de Marrakech à Tombouctou (Utazás a Szaharán át, Marrákestől Timbuktuig). A szobák útvesztői élménygazdag „,túrát” kínálnak a Marrákesből induló Algérián, Nigeren áthaladó útvonalon Timbuktu végállomásig, ahonnan Mauritánián keresztül ,térhet vissza” a látogató a „,vörös városhoz”. Minden egyes helyiség tulajdonképpen a legendás transz-szaharai karavánút egy-egy meg- 
állóhelyét jelképezi. Az „arany út” bemutatja a bennszülött kézművesség alkotásait, amelyek között szőnyegek, sátrak, hangszerek, szobrok, kerámiák, ékszerek, textíliák, bútordarabok, különleges berber dísztárgyak, tuareg bőrdíszmüvek remekei láthatók. A kiállítás magába foglalja a Nigerben élő fuláni népcsoport fotóanyagát is, amely a gerewol-t, az évszázados udvarlási rituálét mutatja be. Külön szobát rendeztek be a marokkói zsidóság ezüstmunkáinak és kézművestermékeinek, valamint Algéria és Mauritánia etnográfiai kincseinek. Az információgazdag feliratok több nyelven tájékoztatnak a mütárgyakról.

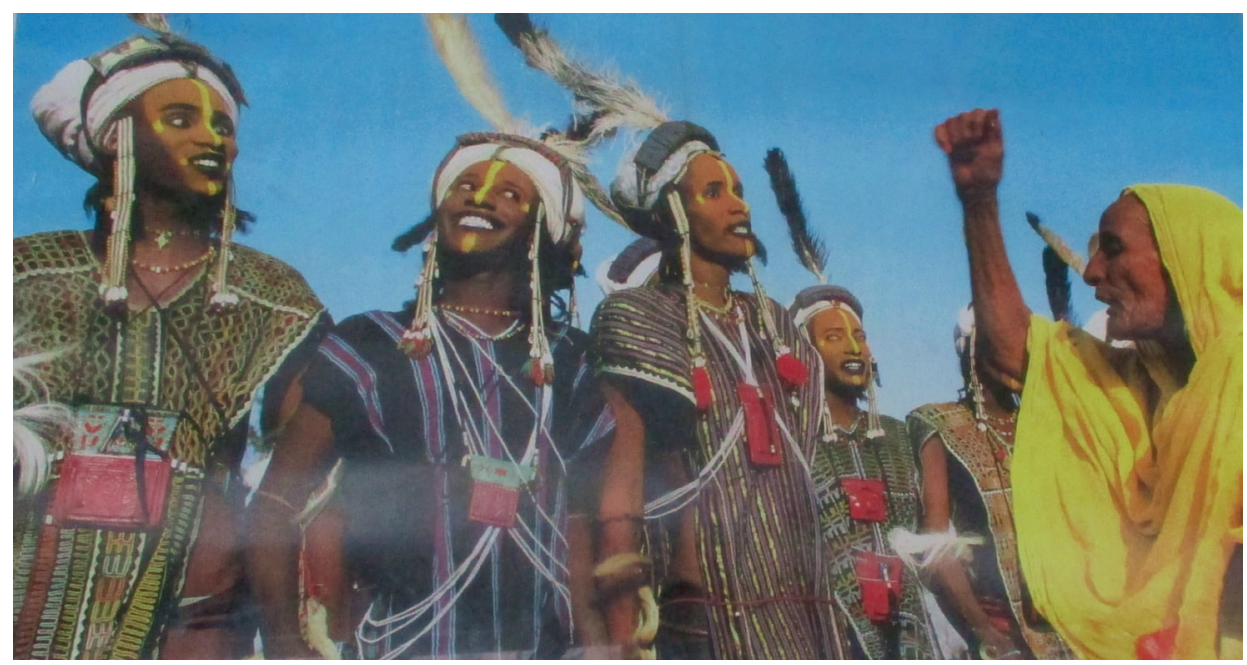

^11. kép A gerewol-t ábrázoló felvétel. Forrás: saját felvétel.

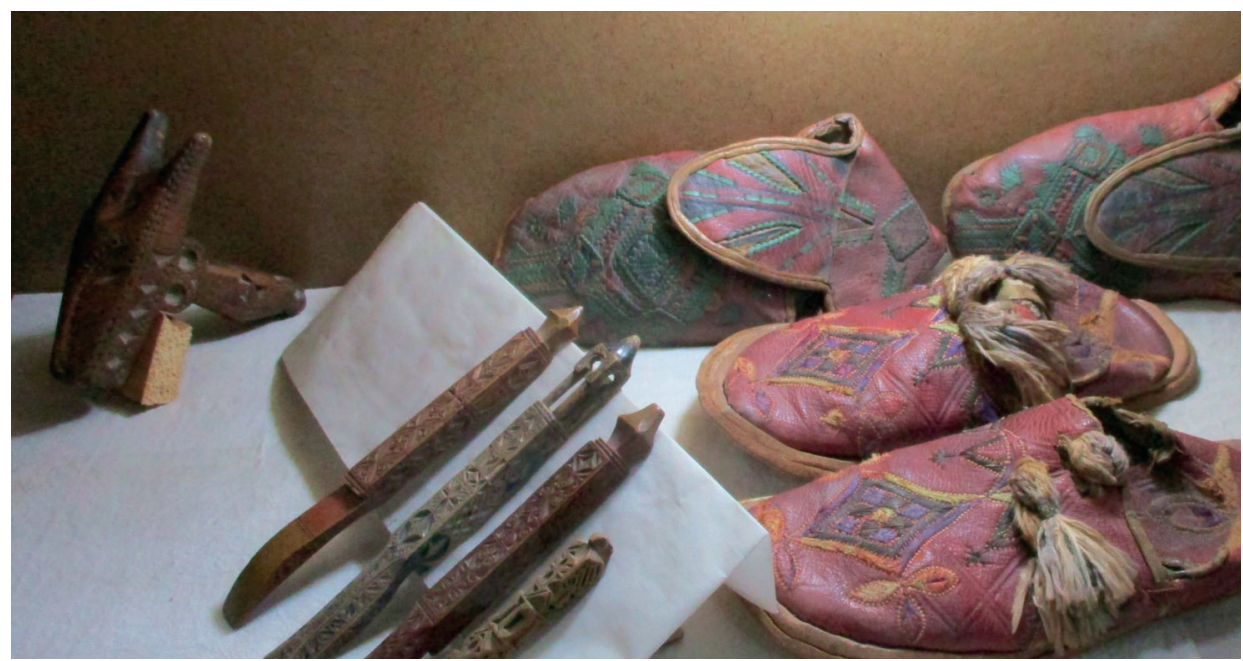

\12. kép Börböl készült lábbelik. Forrás: Sajátfelvétel. 


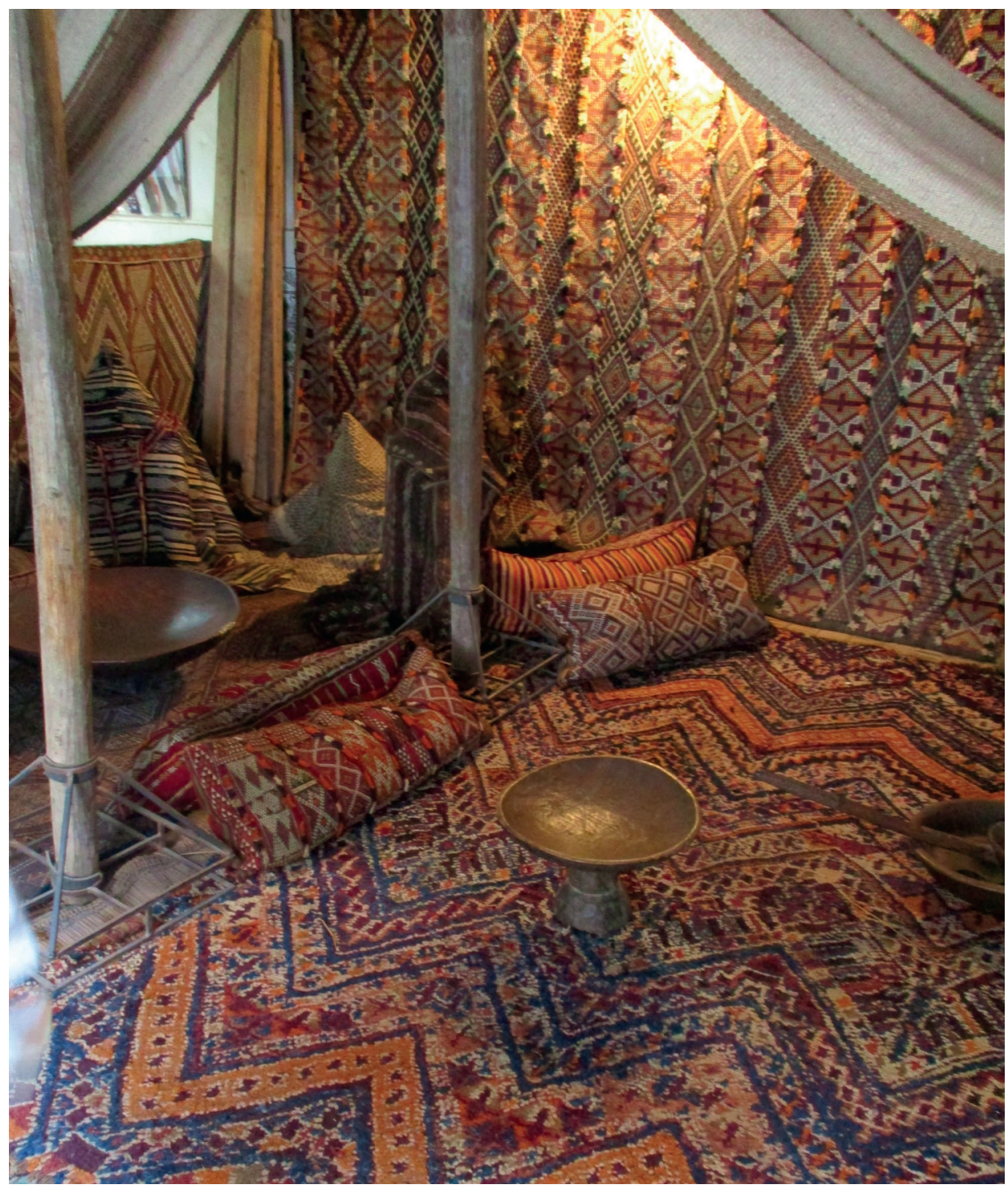

^ 13. kép Berber szönyegek. Forrás: Saját felvétel.

A fent említett memóriaintézmények különféle muzeológiai látásmódról tanúskodnak, amelyek jól kiegészítik egymást. Amíg a medinában található Musée Tiskiwin az antropológiai múzeumi szemléletmód példája, addig a Musée Mohammed VI. pour la Civilisation de l'Eau au Maroc az innovatív építészeti megoldások, a rendhagyó belső térhasználat, az újszerü kurátori koncepció és a multimediális technika muzeológiai célú alkalmazásának egyik recens megtestesítője. Ha a múzeumot médiumként kezeljük, akkor ez utóbbira vonatkozható az a Marshall McLuhan 


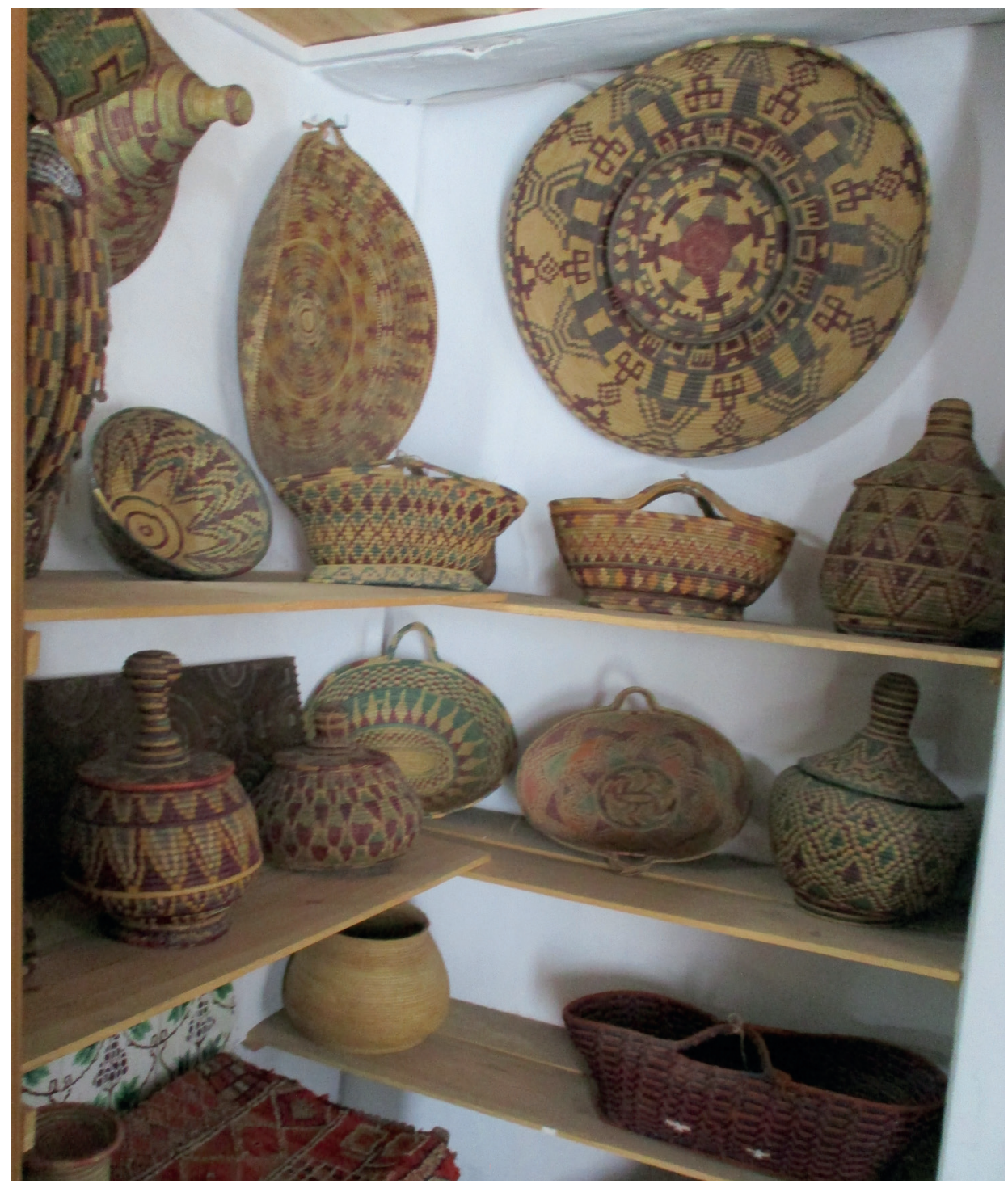

^14. kép Hétköznapi használati tárgyak. Forrás: Saját felvétel.

Understanding Media c. munkájából (McLuhan, 1994.) jól ismert meghatározás, miszerint „the medium is the massage”, azaz már nem egyfajta eszköz, amely pusztán jelentést közvetít, hanem inkább tekinthető a jelentéslétrehozás keretrendszerének. (Pusztai, 2016.) A létesítmény markáns arculata azt az üzenetet hordozza, hogy a helyszín önmagában is képes bekapcsolódni mind a város időfolyamába, mind a nemzetközi gyüjteményezési folyamatokba. 


\section{Jegyzetek}

1 A kulturális fordulatokról lásd bővebben Bachmann-Medick, 2007.

2 A 'múzeum mint médium' koncepcióról lásd bővebben Putnam, 2001.

3 A posztkoloniális fordulatról kulturális antropológiai megközelítésből Afrika vonatkozásában lásd bővebben Devisch - Nyamnjoh, 2011.

4 Vagy nem látják-e azok, kik tagadnak, hogy az Egek és a Föld egy pontba voltak süritve, majd mi vetettük azokat szét? Megtettük a vízből minden dolgot élővé, hát mégsem hisznek?" Abdel Rahman Mihálffy (Mihálffy Balázs) a Magyar Iszlám Közösség vallási vezetője, agrármérnök, publicista fordítása. (Korán 21:30) (http:/www.islamland.com/uploads/books/ Al-Kuran hun.pdf Utolsó letöltés: 2021. 01. 01.)

5 Az egyik legjelentősebb és legbefolyásosabb arab időszaki periodika, az 1959-ben Rabatban alapított Maghreb Arabe Presse rendszeresen közöl kiállításkritikákat a VI. Mohamed Viz Múzeum tárlatairól. Emellett a Communiqué de Presse Français, a Communiqué de Presse Arabe, a Revue de Presse, a Communiqué de Presse Conférence Ibn Battouta is megjelentetnek írásokat a múzeum gyüjteményeiröl. (http://museeaman.ma/presse Utolsó letöltés: 2021. 01. 01.)

6 (www.watermuseums.net/museum/museum-mohammed-vi-for-water-civilization-inmarocco-aman/ Utolsó letöltés 2021. 01. 01.) E nemzetközi hálózat tagja - egyedüli magyarországi intézményként - az esztergomi Duna Múzeum, hivatalos nevén Magyar Környezetvédelmi és Vizügyi Múzeum.

7 A GIZ 1991-ben három szervezet - a Deutsche Gesellschaft für Technische Zusammenarbeit (GTZ, Német Technikai Együttmüködésért Társaság), a Deutscher Entwicklungsdienst (DED, Német Fejlesztési Szolgálat), az Internationale Weiterbildung und Entwicklung GmbH (InWEnt, Nemzetközi Képzési és Fejlesztési Kft.) - egyesülésével jött létre. Több szövetségi minisztérium - így a Bundesministerium für wirtschaftliche Zusammenarbeit und Entwicklung (BMZ, Szövetségi Gazdasági Együttműködési és Fejlesztési Minisztérium), az Auswärtiges Amt (Külügyminisztérium), a Bundesumweltministerium (Szövetségi Környezetvédelmi Minisztérium) - számára lát el feladatokat. Szövetségi tartományok, önkormányzatok, valamint magánszemélyek megkereséseinek is eleget tesz. (https://www.bmz.de/de/ministerium/ wege/bilaterale_ez/akteure_ez/einzelakteure/giz/index.html Utolsó letöltés: 2021. 01. 01.)

8 A „falakon túlmutató múzeum” koncepcióról lásd bővebben Peyrouse, 2000.

9 Az UNESCO A Global Network of Water Museums adatbázisába bekerült a Burkina Faso fővárosában, Ouagadougou-ban működő Musée de l'Eau. (https://www.watermuseums.net/ network/ Utolsó letöltés: 2021. 01. 01.) E szervezet ugyanakkor nem listázza az ugyancsak számottevő tematikus emlékanyaggal rendelkező fokvárosi Waterworks Museum-ot.

10 II. Hasszán (1929-1999) - az Alavita-ház tagja, 1961-től marokkói király-kezdeményezésére indult el az országban a víz elosztását és higiéniai ellenőrzését megcélzó gátépítési projekt.

11 VI. Mohamed (1963-) marokkói király, apja, II. Hasszán halálát követően 1999-ben lépett trónra.

12 A 'nória' a folyó erejét a víz átemelésére hasznosító föként az ókorban használatos kerék, egyes példányai a mai napig müködnek. A kifejezés a spanyol 'noria' szóból származik, amely 'horkolót' jelent utalva a szerkezet által keltett zajra. (Oleson, 2000: 217-302.)

\section{Felhasznált irodalom}

- Bachmann-Medick, Doris (2007): Cultural Turns. Neuorientierungen in den Kulturwissenschaften. Reinbek bei Hamburg. Rowohlt Taschenbuch Verlag.

- Beier-de Haan, Rosmarie (2005): „Posztnacionális, transznacionális, globális? A történeti muzeológia jelene és kilátásai.” Múzeumi Közlemények. Különszám. 15-24. 
- Clifford, James (1999): „Az etnográfiai allegóriáról.” (ford.) Vörös Miklós. In: N. Kovács Tímea (szerk.): A kultúrák narrativái. (Narrativák 3.) Budapest, Kijárat Kiadó, 151-179.

- Clifford, James - Marcus, George E. (eds.) (1986): Writing Culture. The Poetics and Politics of Ethnography. Berkeley - Los Angeles - London: University of California Press.

- Devisch, René - Nyamnjoh, Francis B. (eds.) (2011): The Postcolonial Turn. Re-Imaging Anthropology and Africa. Bamenda - Buea (Cameroon), Langaa Research and Publishing Common Initiative Group.

- Karp, Ivan - Lavine, Steven D. (eds.) (1991): Exhibiting Culture. The Poetics and Politics of Museum Display. Washington - London: Smithsonian Institution Press.

- Korff, Gottfried - Roth, Martin (Hrsg.) (1990): Das historische Museum. Labor, Schaubühne, Identitätsfabrik. Frankfurt am Main - New York - Paris, Campus Verlag - Éditions de la Maison des Sciences de l'Homme.

- Lidchi, Henrietta (1997): „The Poetics and the Politics of Exhibiting Other Cultures”. In: Hall, Stuart (ed.): Representation. Cultural Representations and Signifying Practices. (Culture Media and Identities series). London: Sage - Open University, 151-222.

- McLuhan, Marshall (1994): Understanding Media. The Extensions of Man. (Introduction by Lapham, H. Lewis.) Cambridge (Massachusetts). The MIT Press.

- Peyrouse, Anne (2000) Au-delà des murs. Nouvelles at contes. Qubèc, Éditions Le loup de Gouttière.

- Pusztai Bertalan (2016): A turizmus mint médium. Replika, 1-2. (96-97. sz.), 11-17.

- Putnam, James (2001): Art and Artifact. Museum as Medium. New York, Thames \& Hudson.

- Oleson, John Peter (2000): „Water-Lifting”. In: Wikander, Örjan (ed.): Handbook of Ancient Water Technology. (Technology and Change in History 2). Leiden, Brill, 217-302.

- Wilhelm Gábor (2013): Az új muzeológia fogalmai és problémái. Néprajzi Látóhatár. 22. évf. 2. sz., 8-29. 
A szerzőröl

doktorjelölt, ELTE BTK

Történelemtudományi

Doktori Iskola,

Atelier Interdiszciplináris

Történeti Tanszék

Kutatási terület:

a kulturális javak

történeti értelmezése,

kritikai örökségtanul-

mányok

About the Author

PhD candidate, Eötvös

Loránd University, Fac-

ulty of Humanities -

Doctoral School in

Historical Studies,

Atelier Department for

Interdisciplinary History

Research areas:

historical interpretation

of cultural goods, critical

heritage studies.

(C)

zoltanotto29@gmail.com

\section{English Abstract}

\section{"Liquid heritage" of Museum Mohammed VI for the Water Civilization in Marrakech}

For the challenges of postcolonial existence in Morocco, being addressed as social organizing factor in the culture, answers are being searched at local, national and global levels. The Museum Mohammed VI for the Water Civilization in Marrakech plays a key role in the conservation and presentation of water supply as natural resource based on material culture. This museum presents the historical and cultural role of water, the diversity of social and spiritual contents associated with it, distinctly the traditional paradigms of representation. The cultural center tries to get involved in the international museum circulation, open to new possibilities of architectural solutions, visual tools and arranging of exhibitions. According to the curator's choice, the main task is to preserve the memories of the past and by reinterpreting those with exhibiting activities reflecting the heritage. The staging of water conservation is realised by using interactive techniques and provides a reflexive experience for visitors. Who is receptive to historical, cultural anthropological approaches may feel addressed, in the meantime the visitor who is interested in technical sciences, geography, geopolitics and applied chemistry finds his account in the exhibition. The innovative museum is an integral part of Al Hamra's tourism and cultural industry, even as the Tiskiwin Museum, which reflects the museum anthropological perspective, located in the medina. The two memory institutions also illustrate the diversity of the city's cultural image. 